\title{
RESEÑA: AUSTRALIA AND GALICIA: DEFEATING THE TYRANNY OF DISTANCE/AUSTRALIA E GALICIA: VENCENDO A TIRANÍA DO AFASTAMENTO. MARÍA JESÚS LORENZO MODIA AND ROY BOLAND OSEGUEDA (EDS.) ${ }^{1}$
}

\author{
Elena Ma González-Herrero Rodríguez ${ }^{2}$
}

\begin{abstract}
Lorenzo Modia, M. J. and R. Boland Osegueda (eds.). 2008. Australia and Galicia: Defeating the Tyranny of Distance/Australia e Galicia: vencendo a tiranía do afastamento. Sydney: Antípodas Monographs. 355/373 pages. ISBN: 0-9775868-1-2.
\end{abstract}

Australia and its history are widely defined in terms of multiculturalism. Its identity has been forged and cultivated through a dialogue with other traditions and nationalities, mainly European ones. In this respect, it is not surprising that the relations between Spain and Australia are increasingly becoming a reference for cultural and literary studies in both countries. As matter of fact, it cannot be obviated that a new Australian seat for the Cervantes Institute was recently opened in Sydney, thus strengthening the presence of Spanish culture there. There is a great concern among scholars to shed light on the so much discussed Australian identity, and the way towards that definition involves the exploration of the European connections with Oceania. Therefore, in addition to other works which had already treated these connections ${ }^{3}$, the book Australia and Galicia: Defeating the Tyranny of Distance deepens into the social and cultural relations established through the Spanish presence in Australia form the time of the first colonisers to the present moment. This collection of essays is the product of the research of relevant Australian and European scholars who aim at demonstrating that the long physical distance that separates both territories is minimized when one reflects upon the historical and the socio-cultural heritage that has been forged throughout the existence of Australia.

Edited in both English and Galician, the volume is structured into three parts which offer historical, social and literary perspectives respectively. The first one of these sections includes six chapters on the history of the Spanish presence in Australia. It covers a range of time that dates back to the sixteenth century and leads up, through the last migratory waves that took place around the 1970s, to the present day situation.

Date of reception: July 2009.

Date of acceptance and final version: July 2009.

2 Becaria, Departamento de Filoloxía Inglesa, Universidade da Coruña; $\square$ emgonzalez@udc.es.

3 Carlos Fernández-Shaw, for instance, is one of the most widely recognised authors in this field, and he has published several historical works that treat the connections between Australia and Spain among which we could mention España y Australia: cinco siglos de historia. 
Roy Boland, in "The Search for Paradise. Reflection on Historical and Cultural relations between Spain, Galicia and Australia", deepens into the first know data about the existence of Australia, based on the legends that surrounded the first colonisers, but he also emphasizes the presence of Rosendo Salvado and his mission which contributed to the amelioration of the living conditions of the often enslaved aborigines. Migration throughout the second half of the twentieth century is another point treated in this essay. Apart from discoursing on the several programmes under which Spanish people migrated to Australia, Boland reflects on the survival of the settlements in which those movements resulted and on the extensive cultural implications that they have in the mixture of civilisations that characterises the country. The inheritance of successful projects and business throughout the generations and the growing interest in Spanish studies by Australian universities serves as significant evidence of the persistent and evolving presence of Spain in Australia.

And if Professor Roy Boland, in his exhaustive introductory chapter enhanced the figure of Rosendo Salvado, the book includes three additional essays devoted to his deeds: "Circulating Correspondence: Rosendo Salvado's Letters in Galicia and Andalusia", "Bishop Salvado, Founder of New Norcia: between Acculturation and Colonisation" and "The Diaries of the Galician Rosendo Salvado. Chronicle of a Spanish Mission in Western Australia" written by Father David Barry, Avelino Bouzón and Roberto H. Esposto respectively. These three articles, although independent, are articulated in a way that they succeed in giving a complete account of the figure of Salvado, which proved so transcendental for the creation and maintenance of the bonds that unite Australia and Spain.

Over the years that followed the first colonising waves in Australia, intensive missionary work was carried out all throughout the new continent, and, by the late nineteenth century, Rosendo Salvado's was the first important Spanish presence there. A Benedictine monk from Tui, Salvado went to Australia yearning to fulfil his missionary spirit, and he developed a work that exceeds the limits of the evangelization: he spread education among the aborigines introducing them to the occidental culture in a manner that their own customs and traditions were preserved as much as possible; he also founded the New Norcia Abbey and established a model for economic planning that promulgated self-sufficiency (Díaz-Fierros Viqueira 2001: 15). Salvado has been studied by many scholars, among whom George Russo stands out for his work Lord Abbot of the Wilderness; and, further than that, his Historical Memoirs of Australia, an essential element in the study of the relations between Australia and Europe, has also been translated into English by E.J. Stormon.

Father David Barry, from New Norcia Monastery, has been carrying out an extensive research on Salvado's correspondence with Spain, which he exposes in his article. The look into the letters written by the Cordovan priest Espinosa to Salvado when the latter was already in his mission in Australia is, in many ways, the starting point that leads to an awareness of the preoccupations and troubles that Salvado's mission had to face, being economic fluctuations as well as the slow pace at which evangelisation progressed some instances of this fact. Additionally, this article clearly proves Salvado's transcendence as an essential bond between two lands; especially if we take into account the fact that his letters did not only reach Espinosa, but also the rest of his community, to whom Espinosa frequently read them. 
Taking the same line as Father Barry, Avelino Bouzón gives in his essay a detailed account of Salvado's life and works, outlining his interesting personality and highlighting his status as a man of letters and also his work as a diplomatic and as an ethnologist. Apart form covering Salvado's life, Bouzón's work also serves as a perfect account of the context that surrounded the early years of colonisation and evangelisation in the nineteenth-century Australia.

Finally, Esposto's research completes this in-depth view on the figure of Salvado, by treating his diaries, an evidence of everyday life in the New Norcia community and an essential key reference for studies on historical relations between Australia and Spain. It is important to remark that Esposto also deepens into the idea of the Terra Australis Incognita as the social utopia created by the first colonisers. He explains the main theoretical points of the practice carried out in that new land by a Catholic Church that intended to restore its primitive roots, threatened by the anticlericalism of the time, and to defend the natives whom they introduced to monasticism as an example of a perfect way of life. Esposto concludes that Salvado and this humanist Christian conception did help all those Aborigines, who were neglected by the government, to survive. Salvado, in Esposto's own words, "could be said to be an early champion of Aboriginal rights." (Lorenzo Modia and Boland Osegueda 2008: 82)

But the historical relations between Spain and Australia, in this volume, are treated also from other perspectives. In this sense, the field of commerce is the focus of Victor Migués's article, in which he emphasises the importance of Corunna's port as the location for the House of Maluccas, which aimed at the activation and control of spice trade with the Pacific area in the sixteenth century, in the same way that Seville's trading house had been doing with the commerce with the Indies. Although, apparently, the various expeditions that departed from Spain did not succeed in establishing themselves in the Pacific Islands and, after a few years, the project was finally given up, Migués highlights the importance of a hypothesis held by Professor Robert Langdon. According to Langdon, the San Lesmes, which was thought to be wrecked and lost or even attacked by some Portuguese ship, might have found the coast of New Zealand, and the crew could have mixed with the native population. In this sense, the San Lesmes, could be considered as the first contact between Galicia and Australia, and the project of the trading house in Corunna would have propitiated it. In sum, Migués's article results interesting as far as it starts treating the history of commerce between the Spanish metropolis and its colonies, to focus on the case of the Pacific islands, and more precisely on the trading house of Moluccas, giving extensive evidence to justify his contention that the project was of a great importance for the establishment of contacts with Australia.

If, as we have been maintaining, the Spanish presence became a constant feature in the history of Australia, migration was a key factor for the consolidation of the relations between the two countries. Counting on their wide previous experience in the research on the Spanish presence in Australia, María Xosé Rodríguez Galdo and Abel Losada, give in their article an account of Galician migration in Australia, presenting it as an essential aspect 
of the socioeconomic progression of the latter over time ${ }^{4}$. The article provides extensive evidence of the migratory fluctuations that took place from the last decades of the nineteenth century to the 1980s, when they underwent their most important decrease. The economic conditions and the World Wars are revealed as fundamental trigger for these fluctuations. But Galdo and Losada go even further to discuss the different periods in which the migratory waves took place and the way in which both the Australian and the Spanish governments favoured them. They also make reference to the establishment of Galicians in Australia and they comment on the various institutions that immigrants themselves created there. Such is the transcendence of the Galician presence in Australia that, as these scholars say, we currently count on a Centre for Galician Studies in the University of La Trobe and also on several publications on Galician culture.

The second section of the monograph offers a series of articles on contemporary approaches to the relations between Spain and Australia. In this section, the emphasis is not put in history as much as in culture, and thus, we can find essays that treat the presence of both countries in the media or even an interview with Alf Taylor, an outstanding Australian author of Aboriginal origin.

The first article of this section - "Australia in La Voz de Galicia" - is devoted to a bibliometric analysis. Elena Alfaya, presents in her work the development of her research on the presence of Australian news in the issues of the Galician newspaper La Voz de Galicia for the year 2005. The analysis is carried out through a study which leads the author reach conclusions on frequency and productivity through mathematical and statistical methods. In general, Alfaya defends bibliometric work as a way of simplifying extensive research and of giving clear evidence of the tendencies in time with regard to a certain matter of research.

Alfaya's article is followed by Susan Ballyn's invaluable interview with the writer Alf Taylor. As pointed out previously, Alf Taylor, apart from being a renowned Australian author, has aboriginal origins, and more precisely, he is one of the children that belong to the "Stolen Generation"s. In his conversation with Susan Ballyn, he recalls his childhood in the New Norcia Mission and the treatment children were given there. The interview reveals that Alf's childhood marked his progression as an author and consequently it also marked the way in which he faces his writings. In fact, the author points at the existence of child which he intends to be different from him, very probably because of the painfulness that recalling his life in the Mission so vividly would provoke; thus, as Taylor says, while writing his memoirs God, the Devil and Me, "it was easier for me to write his story than [...] to write my own story". (Lorenzo Modia and Boland Osegueda 2008: 156) In general, it can be asserted that Susan Ballyn's interview to Alf Taylor is extremely interesting due to the fact that through it, the reader is given a testimony of a difficult childhood within

\footnotetext{
These scholars have also other publications which revolve around Galician migration not only to Australia but to other destinies as well.

5 Let us remember that after Salvado's death, a period started in which the government made efforts to impose white culture to Aborigines. One of the practices that they used to carry out consisted in stealing children from their families so that they were educated under the principles of the whites, at the same time that they were used as domestic servants. Alf Taylor, together with his brothers and sisters, underwent this situation.
} 
the context of the Australian "Stolen Generation", also shedding light on the way Taylor's experiences determined his work as a writer.

In such a multicultural world as the present-day one, identification and individual values still prevail over the incipient globalisation. The manifestation of the existence of those individualities and values as they configure cultures, together with their recognition and the ways towards their preservation, seem to be the point in common among the rest of the articles that constitute this section of the book. In this regard, both the Australian culture and the Galician one are the points of study in each of the essays.

In this trend, Olga Castro offers an approach to cultural studies through language. She considers colonialism and the peripheral emplacement of both Galicia and Australia key factors in the treatment of what is her main interest: feminism and the representation of women through language, particularly in the English and Galician naming and classifying of reality ${ }^{6}$. This work does not only provide linguistic cases in which the lack of equality between the sexes is evident though language, but it also points at ways towards a solution. Castro resorts to scholars such as Devorah Cameron or Anne Pauwels to affirm that there is a need for a change both socially and linguistically, because, although an adaptation of the linguistic devices to show gender may be the first step towards equality, there must also exist some acceptance as well as some willingness that favour its fulfilment. In this respect, she suggests applying the methodologies of the TEaGIRL project, developed in the University of Perth, to the Galician language as a minority one in a peripheral emplacement. This project, which studies the linguistic devices used to favour gender equality and its relation to the social circumstances that surround it, has been focusing on other minority languages, such as the varieties spoken in Hong Kong, Singapore or Philippines.

And the Galician language and its projection in the Internet are treated in the article "The Potential to Win a .gal Domain to Support World Wide Galician Culture: A View from the Antipodes". Peter Guerrand deals with the importance of the presence of specific cultures in the Internet though the acquisition of their own domain. Taking as a precedent the establishment of the .cat domain for the Catalonian language and culture and the organisations that support and promote them, Guerrand explores the history of the INCANN (International Corporation for Addresses, Nouns and Numbers) and its requirements to reveal the Galician case as a powerful candidate, and the work carried out by the Punto Gal project, in this respect, turns out to be absolutely essential. Moreover, as the article reflects, the existence of a wide Galician presence in the international panorama, not only thanks to the phenomenon of immigration, but also through the divulgation of the language, is one of the most important strong points for Galicia to achieve its own domain.

As we can see, the wide diffusion of peripheral cultures in the present-day world is a growing reality. Further than that, two so far away lands as Galicia and Australia may not be so different as far as that diffusion and the devices used for it are concerned. This seems to be the main thesis of Paula Lojo and Lidia Montero in their article, which is centred upon media studies, and more particularly in the case of TV series and their scope in terms of transnational audience. The article presents a wide theoretical introduction to

\footnotetext{
6 Castro points out that the peripheral position of minority cultures implies the danger to be absorbed by the central ones, which is an added handicap in the way towards gender linguistic equality in those cultures.
} 
continue to deep into the particularities of the series chosen as instances to support their thesis - Neighbours and Mareas vivas. Lojo and Montero analyse the way in which both series show stereotypical behaviours through many of their main characters, reinforcing a sense of identity, and they go further to reveal stereotypes as particular to productions developed in peripheral areas. They also demonstrate that the wide success that both series had out of their frontiers, together with the high position in which they were situated by other culturally different audiences, can serve as evidence of the closeness between them in terms of status.

Elizabeth Woodward's article, the last one in this section, treats the representation of cultural values in the press through the news of the heroic rescue of two Australian miners. Woodward deeps into the way the principles that conform and underlie Australian culture are transmitted to the outsider through the press. Thus, as Woodward asserts, "[n]ot only are culture-specific terms used in the press reports, but, more importantly, they are often glossed by the journalists in order to help non-Australian readers (who are otherwise linguistically competent in English) to understand their exact meaning." (Lorenzo Modia and Boland Osegueda 2008: 232). In the light of this fact, Woodward analyses the Australian sense of humour and the concept of mateship as reflected in the different reports about the miraculous rescue, which she uses to illustrate these concepts.

A particularly interesting aspect of this article is in the author's approach to the aforementioned concept of mateship through the application of the theories of Wierzbicka and Goddard in order to reveal the specificities of certain cultural values as metalinguistic aspects that help determine one's expectations about others. Woodward then, reflects on how the difficulty in understanding the actual meaning of mateship may be in the fact that it does not correspond to any other concept in English, rather, it is an idea which has been elevated to the category of a national sentiment. In general, it could be said that Elizabeth Woodward's article is a very interesting contribution to media studies, as far as it supposes an immersion in Australian cultural values as conveyed through the press from a foreign perspective.

But probably the most interesting section of the book is the third and last one, which is devoted to literature. In fact, literature is, in many occasions a way of transmitting not only personal perspectives or even anxieties but also social realities, and, in this respect, it plays an especially relevant role in all the realities associated to the progress of a nation and its relations to the peripheral surroundings. Australian literature has been for long concerned with the configuration of the Australian nation, looking for a tradition in which to support its own past and build up a future, and the dialogue between this country and Europe has been essential in this respect, as some of the articles in this section prove. And one cannot explore Australian literature and its history without mentioning Patrick White. Although, as Karin Hansson affirms, his status as a major novelist had already been recognised both within Australia and abroad when he was awarded with the Nobel Prize (Hansson 2004: 103), it was probably through that recognition that Australian literature attained the international credit deserved. The importance of White's work was pointed at by the Swedish Academy though an allusion to his having "introduced a new continent into literature." (Lundkvist) It cannot be denied, then, that White supposes a landmark in the history of Australian literature, and he set a precedent for other generations of authors including Peter 
Carey, David Malouf, Murray Bail, Kate Grenville, Richard Flanagan, etc., some of whose works are dealt with in this book.

Issues on the creation of an Australian identity and the relationship of the writer with it have been explored by numerous authors who have provided different perspectives on them. The novelist Peter Carey, includes in Illywhacker (1985) an epigraph quoting Mark Twain in which Australian history is defined as a series of "beautiful lies; and all of a fresh new sort [...] but they are all true, they all happened". The author has recognised the importance that shaping an Australian national identity has for him: "Almost everything I have written has been concerned with questions of [Australian] 'national identity', a seemingly old-fashioned project that seems, to me, an alarmingly modern concern" (qtd. Bliss 2007: 282). David Malouf, for his part, has always been concerned with the relation of the human being to the landscape and the idea of displacement, which he has treated in some of his works, among them the widely acclaimed Remembering Babylon (1993). As he himself affirms, "I think of myself, and almost all the writing, as beginning somehow with the body in a sensual [way], with a strong sense of where the body is, its compactness, and where it impinges on the world around it I suppose that's why I get led so often into all sorts of notions of mapping, of space and boundaries [...]." (Williams 1998: 101).

The reflection on these ideas in his novel Fly Away Peter (1982) is the main point in Elisa Armellino's article. As Armellino explores this novel, she emphasises that in Fly Away Peter, Malouf creates a new concept of home by making frontiers disappear. Through her study of several characters in the novel, one can appreciate different notions of home, ranging from the physical possession of the land as a way of subordination - an image that stands for colonisation - to a especial relation with nature, unattainable but for the native Australian, through which a house can become an extension of it. Being a novel full of oppositions and dichotomies, Fly Away Peter is also a revelation of a sentiment of dystopia, as Armellino argues, a dystopia that becomes evident as the characters in the novel face World War One and the horrors of the life in the trenches (Lorenzo Modia and Boland Osegueda 2008: 245-6). The author continues explaining that this experience enhances the necessity of recovering one's past through the search for one's self. As I pointed out previously, Armellino's article supposes a valuable in-depth journey through some of Malouf's ideas on the relation between the human being and the surrounding as reflected in Fly Away Peter.

Another important author treated in this book is Murray Bail. His novel Eucalyptus is object of study in two articles: "Heroes and Mirrors: The Presence of Corunna in Murray Bail's Eucalyptus and Sally Morgan's My Place" by María Jesús Cabarcos Traseira and “'Stories that Take Root Become Like Things, Misshapen Things.' Murray Bail's Eucalyptus: Contesting Traditional Narratives about the Land and Women in Australia?" by Cristina Fernández Méndez. Let us remember that Murray Bail belongs to the generation of 1970s, concerned with the introduction of innovations in their writings defying of the conventional. Susan Lever alludes to Helen Daniel's definition of this group as "Liars" "in reference to their various moves away from conventional realism" (Lever 313). In this trend, one of the main characteristics of Bail's writing is his negotiation of the boundaries between the real and the fictional — which, as we will see, Cabarcos Traseira mentions in her essay-, but he also puts an emphasis on short story writing, of which he is thought to be an innovator. 
Bail's relevance in this respect can be evidenced through his inclusion in the publication of Brian Kierman's The Most Beautiful Lies ${ }^{7}$, a collection of short stories considered as representative of the revival of this genre.

Altering the order of appearance in the book, I would like to begin with Fernández Méndez's article, which treats Bail's discourse on the land and women in his novel. In the definition and justification of her object of study, she affirms that the fact that Eucalyptus arouses the reader's emotions - which has much to do with its fairy tale discourse - should not overshadow other important issues that ought to be considered. The exploration of the traditional interpretations of the relation between land and woman leads her to analyse the stereotypes present in the main characters in the novel and their acting. The implications of the so colonial act of possessing the land through naming it, a masculine task, as Fernández Méndez explains, is a key point in the analysis, which leads to Bail's idea that naming is not so important, rather, the importance seems to be in the humanity and the diversity present in stories, which "do not only relish the diversity of nature but also the plurality and the differences among human beings" (Lorenzo Modia and Boland Osegueda 2008: 303). Thus, Fernández Méndez concludes, "Eucalyptus does not deconstruct the stereotypes that underlie the Australian tradition, which are behind many of the inequities that are to be seen even today in the country, but it points to the fact that it can, and must, be done" (Lorenzo Modia and Boland Osegueda 2008: 305).

As I have pointed out previously, also Cabarcos treats Bail's novel in her essay. In this case, her work deals with the presence of Corunna in Australian texts and its transcendence. She deeps into Bail's description of Corunna, which is integrated in one of the tales the novel contains, and which, literally "becomes an antipodean mirror image of the novel's main narrative line, both the same and its reverse." (Lorenzo Modia and Boland Osegueda 2008: 259) ${ }^{8}$. Through this story Bail presents Corunna as a magical place, adding some details product of his imagination and conveying the idea that reality and fiction merge in a way that a fictional tale seems to carry more truth than actual personal anecdotes. The most interesting issue concerning this part of Cabarcos' essay is that it reveals, not only a connection between Australia and Galicia, but also the Australian fictional perspective through which Bail approaches an antipodean land, questioning, once more, the limits between reality and fiction.

Moreover, before dealing with the case of My Place by Sally Morgan, Cabarcos points at Charles Wolfe's poem "The Burial of Sir John Moore after Corunna", which authors such as Lord Byron, Alan Poe, George Orwell or Benedict Anderson have praised for its quality and its patriotic essence, reaffirming the undeniable presence of this text in the English literary canon. It is her thesis that the presence of Corunna - as a surname and also in the place name "Corunna Downs"- in Morgan's autobiographical novel has its origins in Wolfe's poem. Therefore, she explains that, as a referent for English patriotism, the name

\footnotetext{
This collection includes short stories written by other four important authors as well: Peter Carey, Frank Moorhouse, Michael Wilding and Morris Lurie, and its complete title was, in fact, The Most Beautiful Lies: a collection of stories by five major contemporary fiction writers.

8 Cabarcos continues explaining that, in the story, not only the setting is antipodean, but also the main character, which would be the reflection of Helen, the addressee of the tale, is a man, making the mirror effect explicit in both geographic and gender terms.
} 
was used to reveal the colonial power in Australia. It can be said that Cabarcos offers a contrast between two texts in which the presence of Corunna is very explicit. Although in the case of Bail its use is mainly literary, in My Place, Cabarcos succeeds in finding, through Wolfe's poem, a more political perspective by establishing connections with the colonial domination.

Cabarcos's article is followed by David Clark's “"Teenage Wasteland': Adolescents and Adolescence in M. J. Hyland's Novels". Clark deals with the conception of adolescence in the contemporary world through J. M. Hyland's works. He begins by introducing the literary career of the author, putting also an emphasis on her personal experiences which he affirms are somehow present in Hyland's writings. In the novels How the Light Gets In (2003) and Carry me Down (2006), Clark finds two examples of the discordance between a decadent society and two teenagers who are progressively loosing their "state of grace", and he seems to convey the idea that it is this confrontation what leads these teenagers to strengthen their belief in their uniqueness as individuals. Furthermore, How the Light Gets In leads Clark to reflect upon a colonial relation between Australia and the United States, and he asserts that " $[\mathrm{t}]$ he two former colonies [...] share a postcolonial reality which reveals the United States as the new colonial power [...] and Australia as a client state." (Lorenzo Modia and Boland Osegueda 2008: 279). David Clark's article is extremely interesting; not only because of his thorough study of Hyland's life and works, but also because of the important social point it treats. As he very appropriately concludes, "Hyland's fictional recreation of adolescent anxiety foregrounds the need for contemporary Western society to re-evaluate the situation of young people in the period between childhood and adulthood, between grace and disgrace" (Lorenzo Modia and Boland Osegueda 2008: 288).

The representation of the concept of nation is the main point treated by Carmen María Fernández Rodríguez in the essay "From Ireland to Australia: Gendered Illustrations of the Nation in Maria Edgeworth's Ennui and Rosa Praed's Lady Bridget in the Never-Never Land'. As it can be inferred from the title, in her approach to this issue she uses the feminine perspective as her main tool, thus addressing the idea of national identity through the narrative of women and establishing a relation in the methods of representation of the nation in the Australian and the Irish contexts. The article reveals that there is clearly a primitive fantastic scent in women's narratives that works for the preservation of the nationalistic and to the detriment of the colonial English forces. Through the characters of the women in these authors' novels, Fernández Rodríguez deeps into the strategies used to reveal a reality that needs to be made justice. Probably the most attractive aspects about this article are both Fernández Rodríguez's convincing discourse and her reflections on the nature of colonies and women, which she reveals as "beings condemned to inhabit the alien environment of culture, strangers in their shadows, with an imposed history but lacking a history of herself" (Lorenzo Modia and Boland Osegueda 2008: 316).

As one of the most important figures of contemporary Australian literature, Peter Carey and his work Oscar and Lucinda (1988), studied by critics such as David Callaghan or Bruce Woodcock ${ }^{9}$, is the object of study of both María Jesús Lorenzo Modia and José Miguel

9 David Callaghan has written an essay on this work by Carey entitled "Meter Carey's Oscar and Llucinda and the Subversión of Subversión", apart from other important publications on Australian studies such as "What 
Alonso Giráldez in their article "Misfits in the Hands of Destiny: Peter Carey's Antipodean Conquest in Oscar and Lucinda". The essay emphasises the way in which Carey plays with beliefs, obsessions and incomprehension in a life that is conceived as a continuum that finally leads the human being to pay for the sins committed. Lorenzo Modia and Alonso Giráldez situate Carey's historic novel within the trend of magic realism, giving evidence of the author's recognition of García Márquez as an influence. In this sense, in Carey's novel, objects acquire an especial relevance in the succession of events, they transmit some magic and they are turned into symbols. Colonialism, for instance, is present in this study, through the analysis of the image of the creation of a fragile glass cathedral that stands for the attempt to Christianise aboriginal people, an attempt that is truncated by the tragic ending of the novel. The article also takes into in-depth consideration the cinematographic adaptation of the novel directed by Gillian Armstrong and its similitude with the argument and characteristics of other important films. With respect to this essay, it should be taken into account that its importance not only lies in the fact that it deals with one of the most prominent figures of contemporary Australian literature, but also in the fact that these scholars are able of transcending a superficial reading of Oscar and Lucinda, deepening into the actual meaning of its elements and revealing Carey's conception of human passions.

Finally, the book closes with an article devoted to Jennifer Strauss's poetic work. In the detailed journey through the Australian author's production, in which Socorro Suárez Lafuente guides us, an especial emphasis is put in the poet's progress from the personal to the social, giving poetry a universal and "cosmic", in Suárez Lafuente's words, nature. As Strauss explores in her work the various roles of women and their definition through society, Suárez Lafuente establishes an scheme that dominates the whole essay, in which these roles are related to several factors that have always determined them such as time, place, history or myth, all of them stemming from Eve down through the evolution of woman. Therefore, she follows this scheme as she goes through a wide selection of poems. This is clearly a polyhedral article which discusses in detail the reflection in Strauss's poetry of many issues of extreme significance for feminist studies. Among many others, we may consider, for instance, one that has been for long treated by many authors and thinkers: the idea that the subordination of woman is implicit in the history of Genesis. The critic highlights Strauss depiction of Eve as a subversive woman who is able of turning Adam's sense of supremacy into a feeble state, creating, somehow, a precedent for women to work against the masculine discourse through historiography. In this sense, I would like to remark this article's interest within the field of both Australian literary studies and feminist thinking.

In general it can be asserted that Australia and Galicia: Defeating the Tyranny of Distance is a volume which provides the reader with much more than a historical, social and cultural context, it reinforces the existence of a dialogue between Australia and Spain, deepening into questions of identity and multiculturalism. Although the book, as a collection of well assembled articles, is extremely interesting and offers a multilateral and complete view of the cross-cultural relations between the two countries, I cannot avoid remarking that the third part, devoted to literature, is especially revealing and valuable. If there would

Future the Aborigine?". In the case of Bruce Woodcock, he is the author of the well known work Peter Carey, which treats the writings and career of this author. 
be something to object, I would probably mention the emphasis put on women studies and contemporary prose, for the detriment of poetry, to which not many essays are devoted. In any case, this volume is, without any doubt, a landmark in Australian and Spanish cultural studies.

\section{REFERENCES}

Buiss, C. 2007. "Peter Carey". A Companion to Australian Literature since 1900. Eds. N. Birns and R. McNeER. Rochester: Camden House, 281-292.

Callaghan, D. 1988. “What Future the Aborigine?”. TIME Australia 3, 32: 12-15. 1990. "Peter Carey's Oscar and Lucinda and the Subversion of Subversion". Australian Studies 4, 20-26.

CARey, P. 2003. Illywhacker. London: Faber \& Faber.

Díaz-Fierros Viqueira, F. 2001. “Unha lembranza necesaria”. Exposición Frei Rosendo Salvado (1814-1900): O bispo dos sen alma. Santiago de Compostela: Consello da Cultura Galega.

FERnÁNDEZ-Shaw, C. 2000. España y Australia: cinco siglos de historia. Madrid: Dirección General de Relaciones Culturales y Científicas.

George Russo, M.A. 2001. O señor abade do ermo. A vida e época do Bispo Salvado. C. Díaz-Fierros Tabernero (trans.). Santiago de Compostela: Conselllo da Cultura Galega.

Hansson, K. 2004. "Patrick White. Existential Explorer". Nobel Laureates in Search of Identity and Integrity. Voices of Different Cultures. Ed. A. HaLlengren. Singapore: World Scientific. 103-116.

LEVER, S. 1998. "Fiction: Innovation and Ideology". The Oxford Literary History of Australia. Eds. B. Bennet and J. Strauss. Oxford: Oxford University Press. 308-331.

Lorenzo Modia, M. J. and R. Boland Osegueda, eds. 2008. Australia and Galicia: Defeating the Tyranny of Distance/Australia e Galicia: vencendo a tirania do afastamento. Sydney: Antípodas Monographs.

LundKVIST, A. "Presentation Speech”. The Nobel Foundation 1973. http://nobelprize. org/nobel_prizes/literature/laureates/1973/presentation-speech.html (7 July 2009).

Stormon, E.J., ed. 1998. The Salvado Memoirs. Western Australia: University of Western Australia Press.

Williams, B. 1998. In Other Words. Interviews with Australian Poets. Amsterdam and Atlanta: Rodopi.

Woodcock, B. 1996. Peter Carey. Manchester: Manchester University Press. 